\title{
Reproductive citizenship in Turkey: Abortion chronicles
}

\author{
Didem Unal $^{\text {a,* }}$, Dilek Cindoglu ${ }^{\mathrm{b}}$ \\ a Department of Political Science, Bilkent University, 06800 Ankara, Turkey \\ b Department of Sociology, Mardin Artuklu University, Mardin, Turkey
}

\section{A R T I C L E I N F O}

Available online 22 March 2013

\begin{abstract}
S Y N O P S I S
This paper discusses the gendered nature of reproductive citizenship in contemporary Turkey through reading the abortion chronicles and exposes the utilization of women's bodies and subjection of women to demographic state policies. To this end, we focus on recent abortion debates originating from Prime Minister Erdoğan's statement on May 25, 2012 that suggested that "every abortion is a murder". Our paper is a qualitative analysis of the arguments of the members of the parliament following PM's statement on abortion. We documented and contextualized the recurrent themes; (1) abortion as a rhetorical tool, (2) trivialization of abortion, (3) medicalization of abortion, (4) abortion in the cases of rape, (5) abortion as an economic imperative. As a result, we unravel the gendered discursive limits of "pro-abortion" arguments in Turkey and reveal the frameworks within which the political debates are shaped when women's bodies, sexualities and reproductive capacities are at stake.
\end{abstract}

(c) 2013 Elsevier Ltd. All rights reserved.

\section{Introduction}

Modern state power is consolidated through application of political power on different aspects of human life and body. Fertility control and discipline of bodies have been at the very center of the modernization project in modern Turkey as well as other countries. Since the nineteenth century, regulation of women's reproductive capacities has become part and parcel of the ongoing social and political changes. The demographic policies accompanying the modernization processes in the country produced a new discourse on reproduction. In this vein, Demirci and Somel (2008) argue that Ottoman state modernization in the nineteenth century led to the effective regulation of women's productivity through the introduction of legal, judicial, administrative, medical, pharmaceutical, propagandistic, and educational policies which aimed to prevent abortion and promote maternity. A similar authoritarian and regulatory attitude towards

\footnotetext{
* Corresponding author.
}

reproduction can be detected in the early Republican state, founded in 1923. Displaying a pronatalist approach, the early Republican state introduced a new regulation in 1930 which prohibited both abortion and contraceptives (Gürsoy, 1996: 532). In the post-1965 period, a new phase began in terms of demographic policies, shaped by a concern for rapid population growth and geared towards inducing family planning. Accordingly, one could suggest that regulation of women's reproductive capacities has always been emblematic of social engineering projects in modern Turkey. A recent example of this regulatory attitude towards women's reproduction can be found in the AKP (Adalet ve Kalkınma Partisi - Justice and Development Party) administration in Turkey, a party that has been in power since 2002 and displays an unambiguous pro-Islamic, conservative orientation.

On May 25, 2012, in his speech at the Fifth International Parliamentarians' Conference on the Implementation of the ICPD (International Conference on Population and Development) Programme of Action organized in Istanbul, Prime Minister and AKP leader Recep Tayyip Erdoğan, for the first 
time in his rule, touched upon the issue of abortion and stated that he is against it:

"I see abortion as murder... There is no difference between killing the child in mother's womb and killing her after the birth." (Radikal, 2012a).

Erdoğan restated his position at the AKP Women's Branch Meeting on May 26, 2012 and further denoted that "each abortion is Uludere ${ }^{1 "}$, associating abortion with the mass killing in Uludere, where 34 Kurdish villagers were killed by the Turkish Armed Forces, and implying that abortion is nothing but murder. In addition to opposing abortion, Erdoğan expressed that he is against cesarean sections, which he interprets as a great hindrance to population growth in Turkey:

"I am a prime minister who opposes cesarean births, and I know all this is being done on purpose. I know these are steps taken to prevent this country's population from growing further. I see abortion as murder, and I call upon those circles and members of the media who oppose my comments: You live and breathe Uludere. I say every abortion is an Uludere..." (Hürriyet Daily News, 2012a).

In Turkey, abortion has been legal since 1983 with some restrictions regarding the timing and permission of the spouse. Therefore, Erdoğan's attempt to reconsider women's right to maintain or to terminate a pregnancy has created intense public debates. Most of the MPs from the AKP supported Erdoğan's views on abortion and made public declarations accordingly. Announcing that a legal regulation may be introduced in the near future, the Minister of Health, Recep Akdağ made the following statement:

“...Given our political position, we put the emphasis on the baby's right to live... People are asking about cases in which the mother has been through something bad. If necessary, the state will look after such babies. If we are to pass a law that will call for tougher restrictions on abortion, we definitely have to take some complementary measures." (Hürriyet Daily News, 2012b).

Some MPs from the AKP criticized Erdoğan's anti-abortion discourse yet the effects of their opposition were quite marginal and could not attract a considerable amount of supporters from among the AKP circles. $^{2}$ On the other hand, MPs from the opposition parties, namely the CHP (Cumhuriyet Halk Partisi Republican People's Party), the MHP (Milliyetçi Hareket Partisi Nationalist Action Party) and the BDP (Barıș ve Demokrasi Partisi - Peace and Democracy Party), posed severe criticisms against AKP's anti-abortion initiative. Considering the wide spectrum of arguments countering the AKP's anti-abortion stance, which are mostly raised by the MPs from the opposition parties, in this paper we aim to investigate the streams of these arguments and the themes that recur in these accounts. Since this study dwells upon politicians' public statements, it may be hard to generalize these views as representative of their parties' political position on this matter. This is in part because there is a lack of well-developed party positions on abortion shared with public; rather the party leaders' comments are quite fragmented and unclear. One can also suggest that the opposition was caught off guard in trying to produce counter arguments against Erdoğan's anti-abortion discourses. Although the AKP has been in power since 2002, none of the MPs from the party had declared such an interest before. Therefore, having been caught off guard, the opposition parties' responses to the AKP's antiabortion initiative are more in the form of individual statements, rather than representing a common unified party stance.

It is important to note that not all of these individual statements display a pro-abortion stance that acknowledges women's right to decide if, when and how to bear children. Rather, some of them oppose the government's anti-abortion argument in relation to other political issues and do not develop their argument on the basis of women's right to abortion. Another group strongly criticizes the anti-abortion initiative yet their discourses are hampered by a reluctance to refer to women's autonomy on their bodies. Moreover, some of these individual statements display hybridity in their approach to abortion. They combine the advocacy of women's right to abortion with a discourse that criticizes the AKP's anti-abortion initiative without treating abortion primarily as an issue of women's autonomy on their bodily integrity. This hybridity serves to tone down the pro-feminist tones in their arguments.

To unravel the intricacies characterizing the opposition's stance on abortion and grasp the complexity of their hybrid discourses, it is important to disentangle these lines of thinking, which can be outlined as follows:

(1) Some MPs from the opposition parties interpret Erdoğan's anti-abortion initiative as a cover-up to conceal the controversial facts about Uludere, an incident where 34 Kurdish villagers were killed by the Turkish Armed Forces who had mistaken them as terrorists. In this sense, their opposition to the anti-abortion initiative relies on an argument that has nothing to do with supporting women's right to abortion.

(2) A group of MPs from the opposition parties criticize Erdoğan's initiation of a public debate on abortion by arguing that there are more important and urgent topics on the political agenda than abortion. This perspective obviously trivializes the issue of abortion and attempts to dismiss women's reproductive rights discussions away from the political arena.

(3) Another recurrent theme in the opposition's "proabortion" discourses is the medicalization of abortion. To criticize Erdoğan's statements about abortion, some MPs maintain that abortion is a technical issue which should be reserved for experts - i.e. medical doctors. This argument can be considered as another attempt to depoliticize abortion and remove such "private" issues as women's reproductive rights from politics.

(4) Some MPs oppose the anti-abortion discourse solely by reminding the public of the prevalence of rape cases in Turkey. As a result, they limit the debate on abortion to rape cases and seem to defend the right to abortion only for women who have been sexually violated.

(5) Finally, the framing of abortion merely as an economic imperative for women with limited resources can be detected as another limitation in the opposition's "pro-abortion" discourses. This stance on abortion does not allow for a discursive space where the idea of a woman's autonomy over her body can be voiced. 
Investigating the above-mentioned lines of thinking, this paper aims to reveal the discursive frameworks within which the political debates are shaped when women's bodies, sexualities and reproductive capacities are at stake. By closely reading MPs' "pro-abortion" arguments articulated in response to the AKP's anti-abortion initiative, this study enables us to unravel the discursive limits in the political arena in Turkey, which suppress the arguments in favor of women's full autonomy in the realm of reproduction.

\section{Women's bodies and reproductive citizenship in modern Turkey}

The agenda of citizenship studies has greatly broadened recently and come to include new fields of social policy such as identity politics, gender/sexual discriminations and reproductive rights (Evans, 1993; Voet, 1998; Walby, 1994; Weeks, 1998). As a part of this new cohort of theories on citizenship Plummer (2001: 238), puts forward the concept "intimate citizenship", a concept that helps to investigate "public discourses and stories about how to live the personal life in a late modern world where we are confronted by an escalating series of choices and difficulties around intimacies". This understanding proposes the idea of sexual rights as an extension of the liberal model of social citizenship that is bounded by civil, political and social rights. Another concept utilized to extend the scope of citizenship studies is "reproductive citizenship". Replacing the concepts of sexual or intimate citizenship with the idea of reproductive citizenship, Turner (2008: 52) states that the modern state's attempt to control reproduction is much more essential, when compared to its interest in regulating sexual rights and setting out legitimate forms of intimacy. States have historically been inclined to regulate reproduction with the aim to sustain population growth and reinforce the values and norms of a household constituted by a married heterosexual couple. Contemporary examples clearly reveal how states attempt to determine the conditions of reproductive citizenship with the aim to ensure their own survival. Accordingly, while the People's Republic of China's one-child policy which is aimed at combating overpopulation demonstrates strict regulation of reproduction, in contemporary Russia, Japan and Singapore, states attempt to determine the conditions of reproductive citizenship with the aim at combating depopulation (Turner, 2008: 5). One can safely argue that state power, citizenship and reproduction in modern world are greatly intertwined. As a result, the social rights of modern citizenship are, to a great extent, constituted by a familial ideology of procreation. Turner (2008: 50) notes that households and families as the social mechanisms for the reproduction of society provide entitlements to men and women as reproducers of the nation. Although Turner's reproductive citizenship, which points out the interlockings between citizenship, state power and reproduction, does not exclude men's bodies, it is obvious that state's regulation of the reproductive capacities weigh more heavily on women's bodies. In the Turkish context, a woman's body, imagined as the "carrier of the seed of the nation" (Delaney, 1991), becomes emblamatic of the terms of the reproductive citizenship.

Turner's notion of reproductive citizenship acknowledges the role of biopolitics in state's interest in population. In this sense, it echoes the Foucauldian account about state's attempts to control the reproductive capacities of population. As Foucault (1978) notes, modern administrative power via the ubiquitous means of biopower utilized by diverse institutions such as family, school or medicine, attempts to discipline the body and regulate the population. In the complex network of social control, the body comes under surveillance and is rendered docile by the means of medical, legal, educational discourses. Feminist scholars who reconsider the Foucauldian framework through gendered lenses suggest that the surveillance of women's and men's bodies are not subject to the same degree of social control (Ramazanoğlu, 1993; Sawichi, 1991). They maintain that the Foucauldian framework is gender-blind in that it fails to acknowledge how omnipresent patriarchal codes rendering women's bodies docile are when compared to the regulatory discourses operating on male bodies.

In the late Ottoman social and political setting, modern administrative power also produced regulatory discourses on women's sexualities and bodies. Along with the ongoing social and political changes at the time, a scientific language on "healthy" marriages, which declared the proper age, hygiene and health conditions necessary for a good marriage, and technologies surveying health, morbidity, life expectancy and fertility became widespread in the modernizing context of the country and were backed up by an elaborate discourse on women's sexuality (Duben \& Behar, 1991: 138-139; Kandiyoti, 1998: 281). According to Parla (2002: 18), reformist men in late Ottoman society were in an unconscious quest for fatherly authority that had disintegrated through the encounters with the West. For them, the most terrifying danger threatening fatherly authority was not Western technology but morality, i.e., the inner domain that bears the essential marks of cultural identity. Women's sexually modest identities were deemed to be the first and foremost constitutive feature of this moral domain. In this regulatory discourse, while ideal women in the male imagination were defined through sexual chastity and purity, women who displayed sexually liberated mores and manners were seen as the embodied state of a corrupted morality. ${ }^{3}$ Therefore, one can make a claim that Puritanism attached to female sexuality lies at the heart of the modernization discourse in Turkey.

Demographic policies and regulation of abortion reflect this proliferating discourse on women's sexuality in the late Ottoman context. Demirci and Somel (2008) note that the Ottoman state in the nineteenth century attempted to effectively regulate women's productivity through legal, judicial, administrative, medical, pharmaceutical and educational policies. The criminalization of abortion in 1859 implied that the irrevocable politicization of women's reproductive behavior was an integral part of the ongoing transformations. Miller (2007: 361 ) argues that partial rights of entry into the public political sphere could only be granted to women through regulation of their bodies and sexualities. As a result, a woman's womb came to be defined as a political place that does not belong to an individual woman but to the biological collective.

Regulatory discourse on women's sexuality in the late Ottoman era remained intact in the new Republic founded in 1923. In this new era, the ideal woman was defined as a well-educated, professional, "modern but chaste" woman who actively participates in the public sphere and fulfills her responsibilities as a wife and mother in the familial sphere 
(Durakbaşa, 1998). The patriarchal bargain that was struck between male authority and emancipated women stipulated that women had to protect their sexual modesty in return for the newly granted rights to enter into the public sphere (Kandiyoti, 1988). This elaborate discourse working on women's identities and bodies brought with it strict regulation of women's bodies and reproductive capacities. In 1926, the Turkish government adopted a new Penal Code and introduced new regulations concerning abortion. ${ }^{4}$ Another regulation concerning women's reproductive capacities is made in 1930 , prohibiting both abortion and contraceptive devices. In the post-1965 era, a new approach was adopted with respect to the regulation of population, revisiting the demographic policies of the early Republican period. In 1965, the introduction of a new law concerning population planning rendered contraceptives legal. In the same regulation abortion was limited to serious medical complications. It is only in 1983 that abortion was legalized through the tenth week of pregnancy on the condition that the husband consents to it.

When the regulation of women's reproductive capacities in modern Turkey is examined historically, one can argue that this historical trajectory is characterized by the utilization of women's bodies for social and political projects. As noted above, in the late Ottoman and early Republican periods, women's sexuality had become symbolic of the ongoing social and political changes of society in general. Regulatory policies at the time attempted to control women's bodies by outlawing abortion and encouraging fertility. On the other hand, the post-1965 regulations of women's reproductive capacities, which were shaped by a new concern for rapid population growth and which allowed abortion in case of serious health complications, were not different from the regulatory attempts of earlier periods when viewed from the aspect of initial goal. Both forms of regulation were motivated by an incentive to urge family planning for population control, not by a concern for women's autonomy on their bodies. Erdoğan's anti-abortion initiative becomes more clear when considered in continuity with the historical trajectory presented above. In this sense, both earlier periods and Erdoğan's recent attempts to restrict abortion and c-sections treat women's wombs as spaces to serve broader political interests.

In this frame, Turner's notion of "reproductive citizenship" accounts for the interlockings between reproduction, state power and citizenship in modern Turkey. Modern state's interest in regulation of population produces an elaborate discourse concerning the limits of citizens' reproductive rights as well as the duties they have to perform in the realm of reproduction. It is widely stated that Turkish citizenship is constructed on the basis of single religion, single language, an organic vision of society and duty-based citizenship, which does not recognize ethnic, religious and language-based differences (Üstel, 2004). It is equally important to note the gendered nature of Turkish citizenship. One critical realm to make such a gendered analysis of Turkish citizenship is reproduction. As Turner puts forward in his account of reproductive citizenship, to reflect on the broadening agenda of citizenship studies today, one has to consider state's interest in regulating the population and explain how such an interest in return contributes to the definition of ideal citizenship. One can claim that in modern Turkey citizenship is not only defined through promoting an organic vision of society and duty-based citizenship but also over a certain demographic regime. Accordingly, the definition of ideal citizenship in the late Ottoman and early Republican era is made through encouraging reproduction. Ideal women citizens were defined as those who bear the next generation offspring deeply committed to the ideals of the political regime at the time. In the post-1965 period the terms of citizenship had changed, presenting the ideal woman citizen as knowledgeable about family planning and birth control. Today, Erdoğan's anti-abortion initiative signifies a return to pronatalist policies, which define the ideal woman citizen as someone who "gives birth to at least three children" ${ }^{5}$ and contributes to the state policies by fulfilling her familial roles as mother and wife. The trajectory above clearly demonstrates that the construction of reproductive citizenship in Turkey heavily relies on the utilization of women's bodies for political purposes and defines the ideal woman citizen in line with the demographic policies in force.

\section{The AKP rule and gender in contemporary Turkey}

The AKP rule in Turkey since 2002 has been marked by the rise of conservatization in socio-cultural and political matters, which has generated critical implications for gender relations in Turkey. In the AKP's conservative politics, being a woman is first and foremost defined within the familial sphere through traditional gender codes. The great emphasis in party politics put on women's familial roles as mothers and wives imply that women have been rendered subservient to the unity of family. In line with the central role attributed to the notion of family, attempts have been made to take measures to prevent the disintegration of the family. ${ }^{6}$ Accordingly, in conservative party politics the disintegration of the family is perceived as the most threatening aspect of the modern era Çitak \& Tür (2008). Coşar and Yeğenoğlu (2011: 561) define AKP's gender politics as a peculiar form of neoliberal-conservative patriarchy, borrowing from Islamic patriarchy as well as establishing an intricate alliance between neoliberal and conservative frameworks, which asks women to adapt to global market conditions, yet at the same time to perform normative wife and motherhood roles. Although the AKP initiated significant legal amendments during its administration, ${ }^{7}$ considering the party's reluctance to challenge the traditional gender roles in the familial sphere, it is far from establishing a new gender regime that would comprehensively improve women's status in public and private spheres.

The definition of ideal womanhood in the AKP's conservative mind-set becomes more crystallized when the party's hostility towards feminist political identity is considered. The most overt expression of this hostility can be found in Erdoğan's comment on the protest organized as a reaction to the draft bill criminalizing adultery, whereby feminist women marched to the Grand Assembly with the slogan, "our body and our sexuality is ours". Erdoğan denounced this protest by stating that these "marginal" women, who do not comply with the traditional values of society, cannot represent the ideal Turkish woman. Here, it is quite clear that for the AKP's leadership, ideal womanhood is constructed in parallel with traditional 
gender roles which glorify women's familial roles. The definition of a woman's identity over the familial sphere and motherhood can also be noticed in AKP's call for having at least three children. Akşit (2010) maintains that this call, which operates through the utilization of women's bodies for pronatalist political projects, signifies the beginning of a new period for demographic policies in Turkey. It points out the re-emergence of pronatalism, which imagines woman as "the carrier of the seed" (Delaney, 1991). This understanding of a woman's body as subservient to pronatalist political aims regards the child as the seed of the nation. In this regard, Delaney (1991) claims that with respect to the cultural meanings of reproduction in Turkey, women's bodies are perceived as "the soil" and men's sperm as "the seed", i.e., the essential element in reproduction. The perception of the woman's body as "the carrier of the seed" makes a woman's body vulnerable to societal control and renders her womb subject to regulation by the modern administrative power. The recent anti-abortion initiative, first uttered by Erdoğan and later adopted by other leading figures of the party, can be better interpreted along these lines. The pronatalist motives in this anti-abortion discourse, which represents abortion as a great threat to the population growth in Turkey, stem from the AKP's patriarchal, conservative politics defining women primarily as mothers and women's womb as a place to be regulated for broader political projects.

It is interesting to note that though many MPs from the opposition parties opposed AKP's anti-abortion initiative, these parties do not perform better when their approach to gender issues is taken into account. ${ }^{8}$ Their stance in this regard is characterized by a similar discourse that defines womanhood primarily in the familial sphere. ${ }^{9}$ This is clearly reflected in their "pro-abortion" discourses discussed below at length.

\section{Discursive limits in pro abortion arguments}

Following Erdoğan's statement that the government works on a new law which would restrict the right to an abortion, parliamentarians from the opposition parties, namely CHP, MHP and BDP raised their voice to oppose this possible legislation. As a result, AKP's conservative discourse on women's reproductive rights received a considerable amount of criticism. This paper is based on the content analysis of Hürriyet, Milliyet, Radikal, Habertürk, Vatan and Hürriyet Daily News between May and June 2012 where all the public statements of opposition parties in the Turkish Grand National Assembly were documented. These opposition politicians' statements on abortion were covered, classified and contextualized. The responses of the MPs range from defending women's autonomy on their bodies to deeming the issue of abortion as irrelevant to politics. The "pro-abortion" arguments articulated by prominent political actors are quite discreet in displaying a pro-feminist attitude towards abortion.

The feminist thinking about abortion places women's autonomy at the center. The pro-choice feminist arguments rooted in liberal political theory emphasize women's full authority as right-bearing citizens to make any decision regarding pregnancy and demand the state not to intervene into women's reproductive freedom (Bordo, 1993). Some others criticize this pro-choice thinking by arguing that women do not make "private" choices free from social, economic, and political constraints (Himmelweit, 1988). An alternative to this is the protectionist line of thinking, which points out that the framing of the right to choice as a negative liberty excludes positive state intervention and thus fails to provide the means to realize this right to choose in practice (Petchesky, 1984). Another attempt which reconsiders the pro-choice idea is the legalpolitical theory making abortion rights claims on the basis of a right to bodily integrity. According to this, the right to abortion is understood as the right to realize the legitimacy of the individual woman's projections of her own bodily integrity (Cornell, 1995). In this understanding, right to abortion is presented as an integral part of embodied citizenship and both the abortion decision and the significance of that decision are justified on the basis of a woman's ultimate authority on her sense of self (Smyth, 2002). It is clear that in all these feminist lines of thinking, the issue of women's autonomy is defined as a core value.

A considerable segment of "pro-abortion" arguments articulated by MPs on the political arena in Turkey fail to incorporate into their accounts the idea of women's autonomy. The discursive limits in their speeches indicate that when arguing against the patriarchal discourses the opposition does not always operate along pro-feminist lines. Below, the wide spectrum of these "pro-abortion" discourses is put forward and recurrent themes in these discourses are identified.

\section{Abortion as rhetorical tool}

Upon Erdoğan' statement that "every abortion is an Uludere", which associates abortion with murder and echoes pro-life arguments in conservative discourses, many parliamentarians reacted by accusing the PM for trying to divert the attention from hot issues on the agenda.

Devlet Bahçeli, the leader of the MHP, stated the following:

"PM's remarks which aim to draw attention away from the agenda have gone too far. Especially the remark "every abortion is an Uludere" can never be elucidated and is full of dangers and weirdness." (Habertürk, 2012).

Here, Bahçeli seems to be critical of the affinity that Erdoğan identifies between abortion and Uludere and suggests that these kinds of comparisons may lead to weird conclusions but he does not explain exactly how and why the comparison between abortion and Uludere is flawed. In this same speech, he goes on saying that Erdoğan's aims concerning women's reproductive capacities can never be genuine but may only serve his other political interests (Habertürk, 2012). Moreover, in order to strengthen his theory about Erdoğan's implicit aims in bringing up the issue of abortion, Bahçeli asks why Erdoğan has waited for so long to take action even though he has been in power nearly for the last ten years. Bahçeli's criticisms clearly do not stem from his intention to defend women's autonomy on their reproductive capacities. In latter passages of his speech, he stresses that his party is against abortion but sees it necessary only when there is a medical complication (Habertürk, 2012). Here, in putting the stress on the necessity of abortion, rather than conceptualizing it as a woman's human right, Bahçeli does not present abortion primarily as an issue of women's autonomy. 
Gülten Kışanak, the co-president of the BDP who stands on the other side of the political spectrum, also used similar arguments to criticize Erdoğan's statement and accused him of blurring the agenda:

"He (PM) brought up another debate to cover up the Uludere massacre; he said that 'abortion is murder; I am also against c-sections.' This is exactly the illusionists' hocus pocus trick... He opened up this debate to silence the controversies surrounding Uludere." (Cumhuriyet, 2012a).

As seen above, Kışanak, in a similar way to Bahçeli, interprets Erdoğan's statement as a tactical move to cover up controversies on the political agenda. Yet, in her speech she goes further than simply evaluating Erdoğan's remarks as a cover-up. Kışanak also frames the issue of abortion as a rights debate and questions the PM's attempt to control women's bodies:

“...PM determines whether or not you are going to give birth or how many children you will have. He further comments on the birth method you have to choose... How is it possible to use such sexist language? ... All women, without making any differentiation, should resist, saying 'take your hands off our bodies'." (Cumhuriyet, 2012a).

In her statements above, Kıșanak criticizes the sexist character of Erdoğan's speech and condemns it as an assault on women's identities and bodies. Considering different shades in her argumentation, one could say that her discourse is characterized by hybridity. On the one hand, she marks out the debate on abortion just as a rhetorical tool utilized to shadow other significant matters on the political agenda such as Uludere; on the other hand she incorporates pro-feminist ideas into her argument by strongly arguing for women's right to control their bodies and reproductive capacities. This dual character in her discourse can be attributed to intersections of the debate on abortion with the Kurdish issue. At the last instance, Erdoğan's remarks on abortion did not only affect women's reproduction but also gave way to serious consequences regarding the AKP's policies towards the Kurdish issue. However, when the rhetoric in Kişanak's discourse is carefully evaluated, one can detect that she begins her speech by evaluating Erdoğan's statement as a strategic maneuver and thus prioritizes this theme, which in return tones down the pro-feminist elements in her argument.

Some parliamentarians refrained from evaluating the abortion debate as a cover-up and refused to argue the basis of the association established between abortion and Uludere, by suggesting that one cannot compare and contrast a human right with a mass killing. Articulating this stance, Sebahat Tuncel, an MP from the BDP, for example, stresses that "abortion is a human right whereas Uludere was a massacre where the perpetrators have not been exposed so far" (Cumhuriyet, 2012b). It is possible to suggest that her stance leaves more room for discussing abortion with respect to women's rights nevertheless her position is perceived as an individual MP position not necessarily endorsed by her party.

\section{Making abortion trivial}

Similar to the interpretations of Erdoğan's statement as a tactical move to camouflage hot topics on the agenda, some parliamentarians evaluated the debate on abortion as an attempt to occupy the agenda to no end. They suggested that there are more urgent topics to deal with than regulating women's reproductive capacities. In this sense, Yakup Akkaya, an MP from the CHP, expressed the following:

"While the country has to face so many problems, it is symbolic that the PM has brought up such an issue as abortion..." (http://www.chp.org.tr/?p=73740).

Similar way to this, Namık Havutça, an MP from the CHP, denoted in a local newspaper that the AKP tries to conceal the economic crises in the country by putting the issue of abortion on the agenda:

"PM should leave the issue of abortion aside and has to deal with the economic concerns of the producers. It is totally wrong to busy the agenda with the issue of abortion while the garlic producers in Pamukçu, rice producers in Gönen cannot harvest their crop." (Yenihaber, 2012).

An MP from the MHP, Lütfü Türkkan's reaction to Erdoğan echoes the former statements in this regard:

"PM should deal with the problems of teachers, soldiers, sergeants waiting to be appointed to post ... not with the sexual acts of some people." (Radikal, 2012b).

Drawing on the statements above, one can note that while opposing Erdoğan's views on abortion, some MPs represent abortion as a trivial subject matter that should not overshadow other significant matters on the political agenda. Accordingly, the problem that these MPs identify in Erdoğan's statements on abortion is not the misogynist character of his speech but rather the whole issue of bringing up the debate on abortion itself; they deny the relevance of this debate for the public sphere altogether at this time in history.

\section{Medicalization of abortion}

Another approach utilized by politicians with the aim to criticize Erdoğan's views on abortion, is the medicalization of abortion. ${ }^{10}$ MPs argued that abortion is a technical issue that should be reserved for experts (medical doctors) and thus the political authorities should not have the final say on this matter which is way outside of their expertise. The CHP leader Kemal Kılıçdaroğlu's declaration below clearly exemplifies this stance:

"Their bodies belong to women. I cannot comment on that issue. This does not concern politics. This is a medical procedure. This has to remain between the doctor and the patient... Who can decide on this matter? Of course it is not up to us to decide. It is the doctor who is going to decide. It is not appropriate to call public attention to an issue that remains between the doctor and the patient all around the world." (Hürriyet, 2012).

Kılıçdaroğlu points out politicians' lack of authorization with regard to abortion. Yet, while he delegitimizes Erdoğan's statement about abortion by stressing that abortion is a medical issue that has to be left to experts, he does not touch upon women's right to abortion at all. In other words, the 
medicalization of abortion enables him to keep silent on the matter and provides him a safe room where he can refrain from making a gendered critique of the debate on abortion. Moreover, by deploying such a medicalization discourse, he comes to define the boundaries of the political. In the very same statement he indicates that since abortion is first and foremost a medical issue, "it is not a subject that concerns politics". This perspective, which explicitly de-politicizes women's reproduction, fails to see the complex ways in which the modern state power operates through controlling bodies, especially women's bodies, and thus turns out to be a gender-blind stance.

An MP from the MHP, Özcan Yeniçeri resorts to a similar medicalization discourse when he is asked to comment on the AKP's intention to introduce a new legislation on abortion:

"Abortion is a medical, scientific issue in Turkey. Its terms have been codified by law... It has to be left to medical authorities, to scientists, to the medical society where these kinds of applications are universally realized..." (Milliyet, 2012a).

Yeniçeri's statement resembles Kılıçdaroğlu's stance on the issue of abortion in the sense that they fail to see the inter-connection between politics and medicine.

In contrast to the MPs who avoid defending abortion along pro-feminist lines through conceptualizing it as a technical/medical issue that should be reserved for experts, some political figures resort to the same medicalization discourse with the aim of preventing the government party from carelessly talking about abortion. Accordingly, they apply the medicalization discourse as a tactical strategy to undermine the authority of the male speakers who associate abortion with killing.

Having stated that abortion is a right acquired as a result of women's movement, Kibriye Evren, a spokesperson for the BDPs women's committee, underlines the fact that abortion is a medical issue that is carried out depending on the health of the baby and concludes that considering this, the PM has no right to impose legislation regulating women's bodies (Milliyet, 2012b). In a similar vein, Pervin Buldan uses the same medicalization discourse with respect to the debate on cesarean sections and maintains that "I have had two c-sections; that is to say, it is the doctor who has to decide whether it has to be a vaginal birth or a c-section. They (AKP) have started to intervene into each and every sphere of life; yet after all, both doctors and women should be able to use their initiative on this matter (abortion)..." (Milliyet, 2012c).

From here, one can conclude that by presenting abortion as a medical issue, these women politicians point out the illegitimacy of a male parliamentarian's attempt to deliver an opinion on this matter and suggest he leave the abortion decision to doctors and medical experts. Again, the hybridity of women MPs' proabortion discourses needs to be acknowledged here. Although they utilize the medicalization discourse, which is geared towards depoliticizing corporeal issues and works against women's right to control their bodies, they turn it into a strategy to counter the male speaker's hegemonic argument that aims at nullifying women's choice to maintain or terminate pregnancy.

\section{Defending the right to abortion over rape cases}

With the aim of challenging AKP's conservative, patriarchal pro-life discourses, MPs from the opposition parties limit their discussion of abortion to rape cases. Below are some examples from the MPs speeches, which point out the prevalence of rape cases and argue for the right to abortion in this frame.

MP from the CHP, Ensar Öğ̈̈t states the following:

“...Before abortion, rape cases have to be prevented. What would happen to the lady who has been subjected to a rape crime? Whose fault is it when a disabled girl is raped? ... What will happen to her child? She cannot take care of herself... How will she take care of the baby?" (Milliyet, 2012d).

Here, Öğüt seems to be sure that the right to abortion is unquestionable when a rape case is at stake yet his discourse that reduces the defense of abortion to rape cases, does not provide him a ground to elaborate on the significance of women's choice on this matter. Furthermore, his sexist language, i.e. his remark "what would happen to the rights of a lady who is raped?" is another shortfall in his "pro-abortion" discourse. With the aim to defend the rights of the sexually violated woman, he chooses a vocabulary that would desexualize her. In other words, he uses the term "lady" instead of "woman" but this attempt connotes nothing but a misogynist mind-set.

An MP from the MHP, Ruhsar Demirel's declarations provide another example where we can observe how the right to abortion is defended solely by pointing out the prevalence of rape cases in Turkey:

“...You cannot expect from a woman to give birth to a baby of a rape case. Some colleagues have made some declarations on this issue. I suggest to them the following: they should look into the eyes of a woman who has been subjected to sexual violation. ... I wonder whether they have ever met such a woman, such a child." (Vatan, 2012).

MP from the CHP, Melda Onur's defense of abortion reiterates Demirel's discourse:

“... PM should take into account all those women who have been raped and have become pregnant. What shall we do, are we going to marry them with the rapists?" (Milliyet, 2012e).

As clearly observed in the examples above, MPs defending the right to abortion merely over rape cases do not construct their argument on the basis of women's control on their bodies. This approach limiting the defense of the right to abortion to sexually violated women victimizes women's existence in the realm of reproduction and sexuality.

Nonetheless, it is significant to highlight different layers in women MPs pro-abortion discourses. Even though in some parts of their argument they limit their defense of the right to abortion to rape cases, both Demirel and Onur, in other parts of their discourse, clearly articulate their opposition against the utilization of women's body for political purposes. Demirel strongly states that she is in favor of doing politics 
"together with women, not over women". Similarly, Onur argues for women's agency and autonomy with regard to abortion and c-section and utters that "... it is the woman who will decide on c-section, abortion or vaginal birth... These men have to take their hands off women's bodies."

From here, one could derive that women MPs' pro-abortion arguments contain pro-feminist ideas in various degrees. At one point they may rely on a discourse that is quite reluctant to touch upon women's autonomy of their reproductive capacities; yet at another point, their argument may turn into a pro-feminist argument enunciating that women have the ultimate control on their bodily integrity.

\section{Abortion as an economic imperative}

Another limitation of the pro-abortion arguments can be found in discourses defending the right to abortion solely on socio-economic terms. In response to Erdoğan's remarks on abortion, some MPs underlined that prohibition of abortion would result in the rise of maternal deaths since in this case, women, who cannot afford to have abortions abroad, would attempt to self-induce abortions in backrooms by applying traditional methods.

MP from the CHP, Hülya Güven points out the high rates of maternal deaths in the pre-1983 period in Turkey, when abortion was not legal:

"In the past, weren't women dying because they could not go to a doctor and resorted to feathers, sticks or other traditional methods? We will go back to those days. Those who have the financial means will go to Cyprus or the Greek islands to have an abortion; those poor and uneducated women who cannot go abroad for such an operation will die." (http://www.hulyaguven. $\mathrm{com} / ? \mathrm{p}=5911)$.

By drawing attention to the possible rise in self-induced abortions at home in case of prohibition of abortion, Güven points out a crucial aspect of the current public debate. Yet, this pro-abortion stance, marked by a genuine concern for the possible rise of maternal mortality, does not capture gendered consequences fully. Even though there is no question that those who would suffer the most from a possible ban on abortion would be economically disadvantaged women, this is a limited argument that does not address all women with different needs to have a safe abortion.

Another example where abortion is primarily defined as a necessity that arises due to lack of means to maintain the pregnancy can be found in Aylin Nazliaka's speeches, MP from the CHP:

"The minister cannot show me a single woman who chose abortion not because of a health complication or social and economic problems but willingly and happily. If she can show me such a woman I will give her a diamond ring as present." (http://www.ntv.com/id25354530/).

In another declaration, Nazlıaka goes further in her analysis and carries the debate on abortion on the axis of women's autonomy, without feeling the need to tone down her pro- abortion stance by justifying the right to abortion through inevitable consequences:

“The PM should quit doing politics over woman's body. In brief, I am telling the PM he ought to stop standing guard over women's vaginas." (Milliyet, 2012e).

Reflecting on Nazlıaka's adamant call for women's autonomy and also the limitations in her pro-abortion arguments, it is possible to say that the hybridity in this discourse may have been deployed as a political tactic to voice a "viable" argument that may have an effect on the patriarchal political scene in Turkey. In this regard, one can argue that women MPs take into account the "rules of the game" defined by the male politicians in politics and formulate some parts of their pro-abortion discourses accordingly.

To conclude, criticizing the AKP's anti-abortion initiative, the opposition parties contributed to the circulation of a "pro-abortion" discourse in the public sphere in Turkey. However, when their statements are thoroughly analyzed, it becomes clear that their "pro-abortion" stance is not always motivated by pro-feminist concerns; rather certain discursive limits in their statements hinder their contribution to the public debate on abortion on the basis of a woman's autonomy on her bodily integrity. In this regard, some parliamentarians interpret Erdoğan's anti-abortion discourse as a strategy to cover up important controversial topics such as Uludere. Perhaps quite rightfully, they point out the rhetorical intentions embedded in Erdoğan's speech yet by doing so, some of them fail to touch upon the implications that this anti-abortion initiative generated for gender relations in Turkey. We argue that to evaluate Erdoğan's anti-abortion stance only in terms of the dynamics of rhetoric is a serious discursive limitation of opposition parties' statements that obscures the gendered consequences involved in this public debate. Secondly, some MPs opposed Erdoğan's anti-abortion initiative by suggesting that there are more urgent topics on the political agenda to deal with than regulating women's reproductive capacities. This perspective trivializes the issue of abortion and attempts to depoliticize women's reproductive rights. Another discursive limitation in the opposition's "proabortion" discourses is the medicalization of abortion. This approach presents abortion as a technical issue that should be reserved for experts. Some parliamentarians utilize this medical definition of abortion to define the boundaries of the political and to refrain from making a gendered analysis of abortion debates.

Another theme that recurs in MPs declarations is the defense of the right to abortion with a reference to rape cases. With the aim to justify abortion against AKP's conservative, patriarchal pro-life discourses, MPs frequently give reference to the prevalence of rape cases in Turkey and seem to defend the right to abortion only for women who have been sexually violated out of wedlock. Even though they touch upon a critical point regarding the abortion debates in Turkey, the formation of the pro-abortion discourses solely in this respect does not capture the whole spectrum of the gendered consequences that the anti-abortion initiative gave rise to. Furthermore, some of the MPs prefer to present the issue of abortion exclusively as a socio-economic phenomenon and underline the fact that restricting abortion would result in 
the rise of maternal deaths since women who cannot afford to have an abortion abroad would attempt to self-induce abortions in backrooms. Framing the right to abortion as a socio-economic imperative blurs the potential of the abortion debates to generate a discursive space where arguments for women's autonomy on their bodies could be articulated and the right to abortion becomes inclusive of all women with different needs to have an abortion.

Relying on the interpretive framework above, one can suggest that a discourse defining the terms for "legitimate" abortion has come to the foreground in Turkey as a result of the current debates on women's reproductive capacities. Accordingly, some MPs from the opposition parties defended women's right to abortion in such a way as to define what the legitimate conditions are for a woman to demand abortion. For them, abortion is more legitimate for women who are sufferers of rape crimes or experience financial difficulty. This understanding establishes a hierarchy between different claims to the right to abortion. It grants this right primarily to women who are presented as "victims", i.e., victims of rape crimes or economic hardship; women who demand autonomy on their bodily integrity ${ }^{11}$ are not seen as significant actors in this debate.

The hybridity in women MPs discourses is the other critical aspect of the recent public debate on abortion. Some women MPs articulate a pro-abortion position yet in some parts of their arguments they may be quite wary in defending women's right to abortion. They combine the pro-feminist defense of abortion with an understanding that conceptualizes the issue of abortion regardless of women's choice. The term "discursive opportunity structure" can be helpful here to deconstruct this hybridity and understand the power configurations in the public sphere in Turkey, which favor certain ideas that echo the dominant discourse and exclude other marginal positions.

Discursive opportunity structures refer to ways of thinking that provide political acceptability of specific ideas (Ferree, 2003; Ferree, Gamson, Gerhards, \& Rucht, 2002). They explain the interactive relationship between the discursive context and the speaker's strategic choice to formulate certain discourses. To make her statements more effective within the boundaries set by the hegemonic discourse, the speaker may strategically prefer certain rhetorical tools that would tone down radical elements in her argument. By doing so, she aims to avoid agitating those who are in power positions and represent the hegemonic codes. In this sense, discursive opportunity structures enable the speaker to respond to the challenges of articulating a marginalized position in the public sphere and make her arguments effective vis-à-vis the dominant set of ideas. One can suggest that to counter the anti-abortion discourses and render their arguments effective in the patriarchal political arena, women MPs in Turkey make use of certain discursive opportunity structures. While in some parts of their discourse women MPs strongly argue for women's full control on their bodies, in other parts, they interpret the debate on abortion just as a rhetorical tool or conceptualize the right to abortion solely over rape cases or economic hardship. Furthermore, some of them utilize the medicalization discourse, which is geared towards depoliticizing corporeal issues and works against women's right to control their bodies, but they formulate it it in such a way as to counter the male hegemonic discourse on abortion. Therefore, it is possible to evaluate women MPs' deployment of hybrid discourses as an attempt to make use of certain discursive opportunity structures. This rhetorical strategy helps them to render their arguments more viable and effective in the patriarchal realm of politics.

\section{Conclusion}

In Turkey, modern administrative power has always produced regulatory practices on women's sexualities, bodies and reproduction. States have historically been inclined to regulate reproduction with the aim of sustaining population growth and reinforcing the norms of a household constituted by a married heterosexual couple (Turner, 2008). In the late Ottoman and early Republican periods, women's sexualities had become symbolic of the ongoing social and political changes. Ideal woman in the male imagination was defined through sexual chastity and purity; women were asked to be active in the public sphere yet modest in terms their mores and manners. Demographic policies and regulation of abortion clearly reflect this proliferating discourse on women's sexuality. The Ottoman state in the nineteenth century encouraged maternity and regulated women's productivity. In a similar vein, the early Republican period adopted pronatalist policies to control women's reproductive capacities. In the post1965 era, a new demographic approach was adopted to combat overpopulation, which also successfully introduced certain regulations surveiling women's bodies. Erdoğan's anti-abortion initiative in 2012 can be perceived in continuity with these earlier periods.

Along with this continuity across different historical eras, there are also remarkable commonalities between different political parties' positions on the matter. In this sense, AKP's anti-abortion initiative, mirroring the party's conservative, patriarchal politics which defines ideal womanhood over the familial sphere, reiterates earlier historical periods and previous administration's attempts to utilize women's bodies for political purposes. Yet, when analyzed carefully, MPs from opposition parties do not produce more egalitarian discourses when they oppose against AKP's stance on abortion. Rather, one can allege that their "pro-abortion" discourses are severely restricted by certain discursive limits which do not allow them to form their statements prioritizing women's autonomy.

What is also quite striking in the wide spectrum of opposition discourses is the hybridity that characterizes women MPs' discourses. It is possible to interpret this hybridity as a strategic move on their part to render their arguments more effective in the patriarchal realm of politics. Yet, when evaluated overall, the "pro-abortion" discourses of opposition parties are greatly hampered by discursive limits that do not prioritize the women's autonomy. In their discourses, abortion as a reproductive right is a need to be granted to victimized women, who live under economic hardship or have been subject to rape. By presenting woman solely as "victims" when the right to abortion is at stake, some opposition discourses openly refrain from recognizing women's autonomy in the realm of sexuality and reproduction and thus mirror the AKP's patriarchal mind-set.

Consequently, considering state's interest in controlling the population, it is necessary to recognize the reproductive aspects of the construction of citizenship. Since state power, citizenship and reproduction are deeply interlocked in modern Turkey, familial ideology of procreation plays a significant role in the constitution of the social rights of modern citizenship. This model 
of reproductive citizenship defines the ideal woman citizen in line with the demographic policies in force. Accordingly, the ideal woman citizen is defined as someone who reproduces the political aims underlying the demographic policies. The recent public debate on abortion in contemporary Turkey has brought into the open that women who claim the right to abortion on the basis of their autonomy on their bodies do not count as ideal citizens neither in AKP's anti-abortion statements not in the opposition parties' "pro-abortion" discourses. As a result, it is clear that the terms of reproductive citizenship in contemporary Turkey is reinforced through the utilization of women's bodies and subjection of women to demographic state policies.

\section{Acknowledgements}

This is a truly collaborative work with a professor and her doctoral student. There were many personal, social, and academic inspirations for this paper; including our personal trajectories as women living and working in Turkey, women's resistance movement in Turkey upon the contestations in politics, and finally the sabbatical year that Prof. Cindoglu spent at the IRWAG of the Columbia University in New York City. We also would like to thank our colleague Fatima Sakarya and the editor and the anonymous reviewers of the WSIF for their valuable comments and assistance with this manuscript.

\section{Endnotes}

${ }^{1}$ On December 28, 2011, with the argument that they have detected militants who engage in the cross border smuggling trade and serve the Kurdistan Workers Party's interests, the Turkish Armed Forces conducted an air raid on Uludere, a town in the province of Şırnak, which resulted in the killing of 34 civilians, most of them teenage boys. This mass killing in Uludere has led to intense public debates in Turkey and thus represents a critical moment in the AKP government's policies towards Kurds.

${ }^{2}$ Nursuna Memecan, as a woman MP from the AKP, declared that she is against a possible ban on abortion (http://siyaset.milliyet.com.tr/ak-parti-limemecan-kurtajyasaklanmasin/siyaset/siyasetdetay/08.06.2012/1550936/ default.htm). In a similar vein, Haluk Özdalga, in his article at the daily Taraf also opposed his party's anti-abortion initiative (http://www.taraf.com.tr/ haber/kurtaj-yasagi-yanlis.htm)

${ }^{3}$ Duben and Behar (1991: 199) state that the early Ottoman novels represented "a growing and increasingly unnerving sense that women are getting out of hand." Furthermore, since sexuality as a problematic theme was distanced from the definitions of ideal woman, in order to write about sexuality Ottoman male writers could only refer to concubines or western female characters because the carnal issues were despicable and they could be only associated with the "impure" woman. Such dreads vis-a-vis the ubiquitous effects of modernization revolved around women were not peculiar to the literary realm but were deeply entrenched in the general public discourse.

${ }^{4}$ By authorizing a two-thirds reduced penalty for those who brought about an abortion with the aim to save his own honor, that of his wife, his mother, his daughter, or his sister, this regulation explicitly defines male honor over woman's womb (Miller, 2007: 362).

${ }^{5}$ On March 8, 2008, attending a gathering on the occasion of Women's Day, Erdoğan urged women to have at least three children and warned that failing to preserve a young population would endanger the future of the nation (http:// www.hurriyet.com.tr/english/turkey/8448562.asp?gid=231\&52=52955).

${ }^{6}$ The AKP leadership attempted to add a clause to the Turkish Penal Code in September 2004, which would make adultery a crime. However, criticism coming from the press, women's organization and the EU prevented the AKP from adding the clause into the Penal Code.

${ }^{7}$ In 2004, an amendment has been made in the Penal Code, stating that marriage would not nullify criminal responsibility in the cases of rape. Another change was made in 2005 in the Law on Municipalities, which obliges municipalities with more than 50,000 inhabitants to open women's shelters. In 2009, the Parliamentary Commission for the Equality of Opportunity for Women and Men is formed.

${ }^{8}$ It is argued that the BDP is more sensitive on gender issues in that it allocated significant number of seats to women candidates and operates on a co-leadership model, represented by a woman and man leader. However, when the party's recent pro-abortion discourses are carefully analyzed, one can see that their position on gender relations is also marked by some limitations that prevent some of the MPs in the party from prioritizing women's control on their bodily integrity.

${ }^{9}$ For further discussion on this matter, see Akyüz (2012).

${ }^{10}$ Medicalization connotes the subordination of certain aspects of life to the authority of medicine. Thus, it expands the scope of the modern biopower by introducing regulatory frameworks on practices and experiences which may have left to individual discretion before. When analyzed through gendered lenses, it turns out that medicalization of women's lives may be based upon unequal gender relations. Investigating medicalization of births in Turkey through following women's birth narratives, Cindoglu and Sayan-Cengiz (2010) maintain that the medicalization discourse closely collaborates with traditional gender roles and contributes to the patriarchal control on women's bodies. In this regard, expansion of the scope of medical authority on women's lives cannot be thought in isolation from the prevalent patriarchal codes.

11 This latter position is represented by feminist women who organized protests against the government's anti-abortion initiative by shouting slogans "Take your hands off our bodies".

\section{References}

Akşit, Elif Ekin (2010). Geç Osmanlı ve Cumhuriyet dönemlerinde nüfus kontrol yaklaşımları [Approach to population control in late Ottoman and Republican periods]. Toplum ve Bilim, 117, 179-197.

Akyüz, Selin (2012). Political manhood in 2000s Turkey: Representations of different masculinities in politics, unpublished PhD Thesis, Bilkent University.

Bordo, Susan (1993). Are mothers persons? Reproductive rights and the politics of subjectivity. Unbearable weight: Feminism, Western culture, and the body (pp. 71-97). Berkeley and Los Angeles: University of California Press.

Cindoglu, Dilek, \& Sayan-Cengiz, Feyda (2010). Medicalization discourse and modernity: Contested meanings over childbirth in contemporary Turkey. Health Care for Women International, 31(3), 221-243.

Çitak, Zana, \& Tür, Özlem (2008). Women between tradition and change: The Justice and Development Party experience in Turkey. Middle Eastern Studies, 44(3), 455-469.

Cornell, Drucilla (1995). The imaginary domain: Abortion, pornography and sexual harassment. London: Routledge.

Coşar, Simten, \& Yeğenoğlu, Metin (2011). New grounds for patriarchy in Turkey? Gender policy in the age of AKP. South European Society and Politics, 16(4), 555-573.

Cumhuriyet newspaper (2012a) 'Kışanak'tan Erdoğan'a Kürtaj Yanıtı' (Kıșanak's Response to Erdoğan on Abortion), 29 May, http://www.cumhuriyet.com.tr/? hn=341192.

Cumhuriyet newspaper (2012b) 'Kadınlarla ilgili konularda karar vericiler kadınlardır' (Women are the ones to decide on matters regarding women), 5 June, http://cumhuriyet.com.tr/?hn=342966.

Delaney, Carol (1991). The seed and the soil: Gender and cosmology in Turkish village society. Berkeley, CA: University of California Press.

Demirci, Tuba, \& Somel, Selçuk Akşin (2008). Women's bodies, demography and public health: Abortion policy and perspective in the Ottoman Empire of the nineteenth century. Journal of the History of Sexuality, 17(3), 377-420.

Duben, Alan, \& Behar, Cem (1991). Istanbul households: Marriage, family and fertility (pp. 1880-1940). Cambridge, NY: Cambridge University Press.

Durakbașa, Ayşe (1998). Kemalism as identity politics in Turkey. In Z. Arat (Ed.), Deconstructing images of the Turkish woman (pp. 139-157). NY: St. Martin's Press.

Evans, D. (1993). Sexual citizenship. London: Routledge.

Ferree, Myra Marx (2003). Resonance and radicalism: Feminist framing in the abortion debates of the United States and Germany. The American Journal of Sociology, 109(2), 304-344.

Ferree, Myra Marx, Gamson, William A., Gerhards, Jürgen, \& Rucht, Dieter (2002). Shaping abortion discourse: Democracy and the public sphere in Germany and the United States. New York: Cambridge University Press.

Foucault, Michel (1978). The history of sexuality, vol. I, trans. R, Hurley, Harmondsworth: Penguin.

Gürsoy, Akile (1996). Abortion in Turkey: A matter of state, family or individual decision. Social Science E Medicine, 42(4), 531-542. 
Habertürk newspaper, (2012). 'Devlet Bahçeli'den Kürtaj yorumu' (Devlet Bahçeli's comment on Abortion) 5 June, http://www.haberturk.com/ gundem/haber/748259devlet-bahceliden-kurtaj-yorumu.

Himmelweit, Susan (1988). More than a woman's right to choose? Feminist Review, 29(38), 56.

Hürriyet Daily News (2012a). 'Abortion sparks raging debate in Turkey' 28 May, http://www.hurriyetdailynews.com/abortionsparksraging\%20debate. aspx?pageID $=2 \&$ ni2 21740 .

Hürriyet Daily News (2012b). 'State to take care of babies born out of rape' 31 May, http://www.hurriyetdailynews.com/state-to-take-care-ofbabies-born-out-of-rape.aspx?pageID $=238 \& n I D=$ 22017\&NewsCatID $=339$.

Hürriyet newspaper (2012). 'Siyasetin iși değil' (It's not a concern of politics), 1 June, http://www.hurriyet.com.tr/gundem/20668868.asp.

Kandiyoti, Deniz (1988). Bargaining with patriarchy. Gender and Society, 2(3), 274-290.

Kandiyoti, Deniz (1998). Some awkward questions. In Lila Abu-Lughod (Ed.), Remaking women: Feminism and modernity in the Middle East (pp. 270-289). Princeton: Princeton University Press.

Miller, Ruth (2007). Rights, reproduction, sexuality, and citizenship in the Ottoman Empire and Turkey. Signs, 32(2), 347-373.

Milliyet newspaper (2012a). 'Sayın Başbakan sezaryen oldu mu da ahkam kesiyor' (Did PM have a c-section; why does he talk about it), 30 May, http://siyaset. milliyet.com.tr/sayin-basbakan-sezaryen-oldu-mu-da-sezaryekonusundaahkam-kesiyor/siyaset/siyasetdetay/30.05.2012/1547004/default.htm.

Milliyet newspaper (2012b). 'BDP Kadın meclisi kürtajı savundu' (BDP's Women's Committee Defended Abortion), 27 May, http://siyaset.milliyet. com.tr/bdp-kadinmeclisi-kurtajisavundu/siyaset/siyasetdetay/27.05.2012/ 1545794/default.htm

Milliyet newspaper (2012c). 'BDP'li Buldan: Bedenimize dokunmasınlar' (Buldan from the BDP: They shall not touch our bodies), 1 June, http:// siyaset.milliyet.com.tr/bdp-libuldan-bedenimizedokunmasinlar/siyaset/ siyasetdetay/01.06.2012/1547952/default.htm.

Milliyet newspaper (2012d). 'Önce tecavüz önlensin' (First, abortion has to be prevented), 4June, http://gundem.milliyet.com.tr/-once-tecavuzonlensin/ gundem/gundemdetay/04.06.2012/1548935/default.htm.

Milliyet newspaper (2012e). 'Başbakan vajina bekçiliğini bıraksın' (PM should stop standing guard over women's vaginas), 26 May, http://siyaset.milliyet. com.tr/-basbakanvajina-bekciligini-biraksin/siyaset/siyasetdetay/26. 05.2012/1545483/default.htm.
Parla, Jale (2002). Babalar ve oğullar: Tanzimat romanımı epistemolojik temelleri [Fathers and Sons: Epistemological foundations of the Tanzimat novel]. Istanbul: Iletisim.

Petchesky, Rosalind Pollack (1984). Abortion and woman's choice: The state, sexuality, and reproductive freedom. New York: Longman.

Plummer, Ken (2001). The square of intimate citizenship: Some preliminary proposals. Citizenship Studies, 5(3), 237-253.

Radikal newspaper (2012a). 'Erdoğan: Sezaryenekarşıyım, kürtajbircinayettir' (Erdoğan: I am against c-sections; abortion is murder), 25 May, http:// www.radikal.com.tr/Radikal.aspx?aType $=$ RadikalDetayV3\&ArticleID $=$ $10891 \&$ CategoryID $=78$.

Radikal newspaper (2012b). 'Başbakan: Her kürtajbirUluderedir' (PM: Every abortion is an Uludere), 27 May, http://www.radikal.com.tr/Radikal.aspx? aType $=$ RadikalEklerDetay3\&ArticleID $=1089235 \&$ CategoryID $=77$.

Ramazanoğlu, Caroline (1993) (Ed.). Up against Foucault: Explorations of some tensions between Foucault and feminism, ed. Caroline Ramazanoğlu, London, NY: Routledge.

Sawichi, Jana (1991). Disciplining Foucault: Feminism, power and body. NY: Routledge.

Smyth, Lisa (2002). Feminism and abortion politics: Choice, rights and reproductive freedom. Women's Studies International Forum, 25(3), 335-345.

Turner, Bryan (2008). Citizenship, reproduction and the state: International marriage and human rights. Citizenship Studies, 12(1), 45-54.

Ustel, Füsun (2004). Makbul vatandasin pesinde: II. Mesrutiyet'ten bugüne vatandaslik egitimi [In search of the ideal citizen: Citizenship education from the Second Constitutional Monarchy until today]. Istanbul: Iletișim.

Vatan newspaper, (2012). Bu sapıkları teşvik eder, 31 May, http://haber. gazetevatan.com/busapiklari-tesvik-eder/454656/1/Haber.

Voet, R. (1998). Feminism and citizenship. London: Sage.

Walby, Slyvia (1994). Is citizenship gendered? Sociology, 28(2), 379-395.

Weeks, J. (1998). The sexual citizen. Theory, Culture and Society, 15, 35-52.

Yenihaber newspaper (2012). 'CHP Milletvekili Havutça, Başbakana sert çıktı: Kürtajı bırak, sarımsağını satamayan üreticine bak’ (MP from the CHP, Havutça harshly opposed Erdoğan: Leave Abortion aside, deal with the garlic producer), 7 June, http://www.yenihabergazetesi.net/ index.php?option $=$ com_content\&view $=$ article\&id=127:chp-milletvekilihavutca-babakana-sert-ckt-kuertaj-brak-sarmsan-satamayanuereticine-bak \&catid $=3$ :sicak-haber\&Itemid $=76$ 